\title{
NGHIÊN CỨU CĂN NGUYÊN GÂY BẸNH VÀ YẾU TỐ NGUY CƠ Ở TRẺ BI VIÊM PHỔI KÉO DÀI TRÊN 2 TUẦN TẠI KHOA HÔ HẤP BỆNH VIỆN NHI THANH HÓA
}

Lê Văn Tráng

\section{TÓM TẮT NGHIÊN CỨU}

Tiến hành nghiên cứu trên 120 trẻ tư 2 tháng - 72 tháng tuổi được chân đoán viêm phổi (VP) nằm viện trên 2 tuân tại Khoa Hô hấp - Bệnh viện Nhi Thanh Hóa trong thời gian tư 01/01/2015 đến 30/9/2016.

Mục tiêu: Xác định một số căn nguyên gây bệnh và yếu tố nguy cơ ở trẻ bị viêm phổi kéo dài trên 2 tuân.

Kết quả: Tỷ lệ mắc bệnh tuổi tư 2 tháng - < 24 tháng là 85\%; Tỷ lệnam:nũ là 1.9:1; Trẻ có cân nặng lúc sinh thấp, nhập viện nhiều hơn so với trẻ sinh binh thường, đa số các bệnh nhi đã được điêu trị truớc khi đến viện.

Tác nhân gây viêm phổi kéo dài (VPKD): Vi khuân các loại chiếm 40\%, virus các loại là $34.2 \%$, đồng nhiếm các loại vi sinh vật chiếm 12.5\%, có 8.3\% không tìm được căn nguyên. Trong 50\% vi khuân tìm thấy thuộc vi khuân bệnh viện; 51 trường hợp dương tính với virus và nấm, cao nhất là Respiratory Syncytical virus (RSV) chiếm 27.4\%, virus sởi chiếm 9.8\%, Cytomegalovirus (CMV) chiếm 9.8\% và nấm Candida Abicans chiếm 11.8\%. Tuổi càng nhỏ thi tỷ lệ nhiếm vi sinh vật càng cao; Nhóm tư 2 tháng đến < 24 tháng nhiễm vi khuân, virus cao hơn với tỷ lệ là $77.6 \%$ và $89.1 \%$.

\section{Abstract}

\section{IDENTIFY SOME ETIOLOGIES AND RISK FACTORS IN CHILDREN WITH} PNEUMONIA LASTING MORE THAN 2 WEEKS AT THE RESPIRATORY DEPARTMENT OF THANH HOA CHILDREN'S HOSPITAL

The study was conducted on 120 children from 2 months to 72 months of age who were diagnosed with Pneumonia admitted to the hospital for more than 2 weeks in Respiratory Department Thanh Hoa Children's Hospital from January 1, 2015 to September 30, 2016.

\footnotetext{
${ }^{1}$ Bệnh viện Nhi Thanh Hóa

Chịu trách nhiệm chính: Lê Văn Tráng.

Ngày nhận bài: 15/12/2019; Ngày phản biện khoa học: 18/01/2020; Ngày duyệt bài: 17/02/2020
} 
Objectives: Identify some etiologies and risk factors in children with pneumonia lasting more than 2 weeks.

Results: The prevalence of disease at the age of 2 months $-<24$ months is $85 \%$; The ratio of male to female is 1.9: 1; Children with low birth weight hospitalized more than normal babies, most of the patients were treated before admission.

The causative agent of prolonged pneumonia: bacteria of all kinds account for 40\%, viruses of all kinds are $34.2 \%$, co-infection with microorganisms accounts for $12.5 \%$, with $8.3 \%$ not finding the cause. In 50\% of bacteria found are hospital bacteria; 51 cases were positive for viruses and fungi, the highest was Respiratory Syncytical virus (RSV) accounting for 27.4\%, measles virus accounted for $9.8 \%$, Cytomegalovirus (CMV) accounted for $9.8 \%$ and Candida Abicans accounted for $11.8 \%$. The younger the age, the higher the rate of microbial infection; The group from 2 months to $<24$ months infected with bacteria, viruses was higher with the rate of $77.6 \%$ and $89.1 \%$.

\section{I. ĐĂT VẤN ĐỀ:}

Viêm phổi (VP) là một bệnh nhiễm trùng hô hấp thường gặp ở trẻ em, bệnh có xu hướng gia tăng, đặc biệt là các nước đang phát triển [2]. Theo Tổ chức Y tế thế giới (2007), trong 15 nước có trẻ em VP nhiêuu nhất, trong đó có Việt Nam với 2 triệu trường hợp mỗi năm [6]. Theo Chương trình phòng chống nhiễm khuẩn hô hấp cấp tính thì trung bình mỗi năm một trẻ mắc NKHHCT từ 3-5 lần, trong đó có 1-2 lần VP. Tại Việt Nam tử vong do VP chiếm 75\% tử vong do các bệnh hô hấp và chiếm 30-35\% tử vong chung ở trẻ em [2].

Viêm phổi kéo dài (VPKD) thường xảy ra trên trẻ có nhiều yếu tố nguy cơ như suy dinh dưỡng, đẻ non, các bệnh lý bẩm sinh kèm theo...Song song với thời gian nằm viện kéo dài, đó là nguy cơ trẻ mắc nhiễm khuẩn bệnh viện, suy dinh dưỡng tăng lên. Làm tăng gánh nặng bệnh tật cho gia đình và xã hội, VPKD là một thách thức cho các bác sĩ nhi khoa. Chính vì vậy, nghiên cứu VPKD là rất cân thiết, chúng tôi tiến hành đề tài: "Nghiên cứu căn nguyên gây bệnh và yếu tố nguy cơ ở trẻ bị viêm phổi kéo dài trên 2 tuần tại Khoa
Hô hấp Bệnh viện Nhi Thanh Hóa" với mục tiêu: Xác định một số căn nguyên gây bệnh và yếu tố nguy cơ ở trẻ bị viêm phổi kéo dài trên 2 tuần.

\section{II. ĐỐI TƯỌNG VÀ PHUOUNG PHÁP NGHIÊN CỨU}

\section{1. Đối tượng nghiên cứu}

2.1.1. Đối tượng: Gồm những trẻ từ 2 tháng - 72 tháng tuổi được chẩn đoán VP nằm viện trên 2 tuần tại khoa Hô hấp - Bệnh viện Nhi Thanh Hóa.

\subsubsection{Tiêu chuân chọn bệnh nhân}

*Tiêu chuẩn chẩn đoán viêm phổi [6].

Ho xuất tiết đờm; nhịp thở nhanh; rút lõm lồng ngực, rút lõm cơ liên sườn nặng; tím tái; rối loạn nhịp thở, ngừng thở...; Nghe phổi: ran ẩm nhỏ hạt, có thể kèm ran rít, ran ngáy...; $\mathrm{X}$-quang tim phổi: hình ảnh tổn thương.

*Tiêu chuẩn chẩn đoán VPKD trên 2 tuần:

Có bệnh cảnh của $\mathrm{VP}$ rõ; thời gian nằm viện kéo dài trên 2 tuần.

\subsection{Phương pháp nghiên cứu}

2.2.1. Thiết kế nghiên cứu: Nghiên cứu theo phương pháp mô tả cắt ngang. 
2.2.2. Cõ̃ mẫu và cách chọn mẫu: Theo phương pháp cỡ mẫu thuận tiện.

\subsection{Phương pháp phân tích và xủ lý số liệu}

2.3.1. Thu thập số liệu: Mỗi bệnh nhân được làm một bệnh án nghiên cứu theo mẫu.

2.3.2. Xử lý số liệu: Số liệu được xử lý bằng phần mềm SPSS 16.0, với các phương pháp thống kê thường dùng trong y học.

\section{KẾT QUẢ NGHIÊN CỨU VÀ BÀN LUÂ̂N}

Trong thời gian từ $01 / 01 / 2015$ đến $30 / 9 / 2016$ tiến hành nghiên cứu trên 120 bệnh nhi tuổi từ 2 tháng đến 72 tháng đủ tiêu chuẩn chẩn đoán là VPKD, chúng tôi thu được một số kết quả như sau:

\subsection{Một số đặc điểm của đối tượng nghiên} cưu

3.1.1. Phân bố theo nhóm tuổi và giới

Bảng 3.1. Phân bố theo nhóm tuổi và giới

\begin{tabular}{|c|c|c|c|c|c|}
\hline \multirow{2}{*}{ Giới Tuổi } & \multicolumn{2}{|c|}{ 2 tháng- $\mathbf{2 4}$ tháng } & \multicolumn{2}{|c|}{ 24 tháng-72 tháng } & \multirow{2}{*}{ Tổng số } \\
\cline { 2 - 5 } & $\mathbf{n}$ & Tỷ lệ $\mathbf{~} \%)$ & $\mathbf{n}$ & Tỷ lệ $\mathbf{~ \% )}$ & \\
\hline Nam & 69 & 67.6 & 10 & 55.6 & 79 \\
\hline Nũ & 33 & 32.4 & 8 & 44.4 & 41 \\
\hline Tổng số & 102 & 100 & 18 & 100 & 120 \\
\hline
\end{tabular}

Theo bảng 3.1, kết quả nghiên cứu cho thấy tỷ lệ mắc bệnh VPKD trên 2 tuần vào viện điều trị ở lứa tuổi từ 2 tháng - < 24 tháng là cao nhất (85\%). Trẻ từ 24 tháng đến 72 tháng chiếm tỷ lệ 15\%. Theo NC của Nguyễn Thị Huyền Nga tại Bệnh viện Nhi Trung ương từ 01/09/2012 đến 30/6/2013 thấy tỷ lệ bệnh nhi bị viêm phổi dưới 12 tháng chiếm tỷ lệ $76.13 \%$ [1].

Kết quả nghiên cứu về phân bố giới tính bệnh nhân VPKD trên 2 tuần cho thấy số bệnh nhân nam nhiêu hơn nũ một cách rõ rệt với tỷ lệ nam:nũ là 1.9:1. Để giải thích hiện tượng trẻ nam mắc bệnh nhiều hơn ở trẻ nữ, có ý kiến cho rằng có liên quan đến gen điều hòa miễn dịch trên nhiễm sắc thể $\mathrm{X}$ (X-link), ở nữ có gấp đôi số gen này vì vậy khả năng điều hòa miễn dịch cao hơn nam. Bên cạnh đó cùng lứa tuổi thì phổi của nữ trưởng thành hơn ở nam giới vì vậy trẻ nữ ít bị viêm phổi hơn [6].

\subsubsection{Phân bố bệnh nhân theo cân nặng khi sinh}

Bảng 3.2. Phân bố bệnh nhân theo cân nặng khi sinh

\begin{tabular}{|c|c|c|}
\hline Trọng lượng khi sinh & Số bệnh nhân (n) & Tỷ lệ (\%) \\
\hline$\geq 2500$ gram & 32 & 26.7 \\
\hline$<2500$ gram & 88 & 73.3 \\
\hline Tổng số & 120 & 100.0 \\
\hline
\end{tabular}

Theo bảng 3.2 ta thấy có $26.7 \%$ bệnh nhân có cân nặng khi sinh $\geq 2500$ gram; có $73.3 \%$ bệnh nhân có cân nặng khi sinh < 2500 gram. 
Điều này hoàn toàn hợp lý vì trẻ cân nặng khi sinh $<2500 \mathrm{~g}$ thường do sinh non hoặc và suy dinh dưỡng $(\mathrm{SDD})$ bào thai, khi sinh non sự chưa trưởng thành của hàng loạt các cơ quan cũng như hệ miễn dịch. SDD gây thiếu các chất nên tế bào thiếu nguyên liệu, năng lượng để trưởng thành và hoạt động. Do vậy, các cơ quan, các tế bào miễn dịch sẽ bị suy giảm về số lượng và chất lượng, đặc biệt là suy giảm về miễn dịch qua trung gian tế bào [2].

3.1.3. Thởi gian bị bệnh trước khi vào viện

Biểu đồ 3.1. Thời gian bị bệnh trước khi vào viện

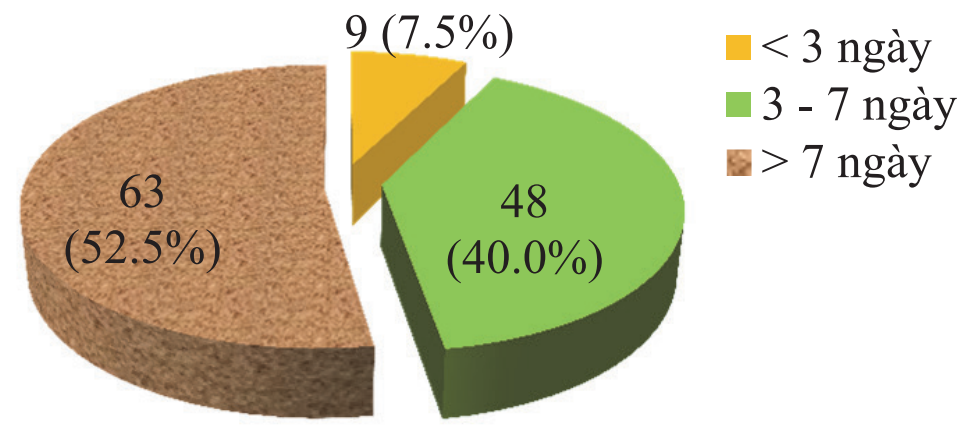

Theo biểu đồ 3.1 ta thấy, $52.5 \%$ số bệnh nhân có thời gian bị bệnh trước khi vào viện $>7$ ngày, tỷ lệ trẻ có thời gian diễn biến bệnh từ 3-7 ngày là $40 \%$. Như vậy, hâuu hết các bệnh nhi không đến viện ngay mà thường tự sử dụng thuốc hoặc điều trị tuyến dưới trước khi vào viện, làm các triệu chứng khi vào viện có thể thay đổi và ảnh hưởng đến kết quả nuôi cấy vi khuẩn.

\subsection{Căn nguyên và yếu tố nguy cơ đến VPKD}

3.2.1. Các loại tác nhân thuiờng gặp gây VPKD

Bảng 3.3. Các loại tác nhân thường gặp gây VPKD

\begin{tabular}{|c|c|c|}
\hline Các loại tác nhân & Số Bệnh nhân $(\mathbf{n})$ & Tỷ lệ (\%) \\
\hline Vi khuẩn các loại & 48 & 40.0 \\
\hline Virus các loại & 41 & 34.2 \\
\hline Nấm & 6 & 5.0 \\
\hline Đồng nhiễm & 15 & 12.5 \\
\hline Âm tính & 10 & 8.3 \\
\hline
\end{tabular}

Trong nghiên cứu ta thấy, các loại vi khuẩn gây bệnh chiếm tỷ lệ $40 \%$, virus các loại chiếm tỷ lệ $34.2 \%$, nấm chiếm tỷ lệ $5 \%$, đông nhiễm các loại vi sinh vật chiếm tỷ lệ $12.5 \%$; $8.3 \%$ không tìm được căn nguyên. Kết quả này cũng tương tự NC của Lê Phước Truyền, Phạm Thị Minh Hồng (2010) khi theo dõi số trẻ em nhập viện do VPKD trên 2 tuần tại khoa Hô hấp BV Nhi đông 2 do vi khuẩn các loại chiếm tỷ lệ 43\%, virus các loại chiếm tỷ lệ 29.3\% [4].

Tương tự NC của Nguyễn Thị Yến, Nguyễn Thị Quỳnh Hương (2012), khi NC nguyên nhân của viêm phế quản phổi kéo dài ở trẻ em $<2$ tuổi tại Bệnh viện Nhi Trung ương vi khuẩn chiếm $45.7 \%$, virus các loại $34.1 \%$ [5]. 


\subsubsection{Phân bố các chủng vi khuẩn theo nhóm}

Bảng 3.4. Phân bố các chủng vi khuẩn theo nhóm

\begin{tabular}{|c|c|c|c|}
\hline \multicolumn{2}{|c|}{ Vi khuẩn } & n (58) & Tỷ lệ (\%) \\
\hline \multirow{2}{*}{$\begin{array}{c}\text { Vi khuẩn Gram dương } \\
(\mathrm{n}=19) \sim 32.7 \%\end{array}$} & S.aureus & 8 & 13.8 \\
\cline { 2 - 4 } & S.pneumoniae & 11 & 18.9 \\
\hline \multirow{4}{*}{$\begin{array}{c}\text { Vi khuẩn Gram âm } \\
\text { (n= 39) 67.3\% }\end{array}$} & H.influenzae & 13 & 22.4 \\
\cline { 2 - 4 } & Acinetobacter Baumarini & 4 & 6.9 \\
\cline { 2 - 4 } & Burkholderia cepaceia & 10 & 17.3 \\
\cline { 2 - 4 } & Klebsella pneumoniae & 4 & 6.9 \\
\cline { 2 - 4 } & Pseudomonas aeruginosa & 4 & 6.9 \\
\cline { 2 - 4 } & Escherichia Coli & 4 & 6.9 \\
\hline
\end{tabular}

Trong 58 vi khuẩn tìm được có 02 vi khuẩn Gram dương (S. pneumoniae và S.Aureus, có 06 vi khuẩn Gram âm (B. Cepacia, K. Pneumonia, P.aeruginosa, H.Influeae, Acinetobacter và E.Coli); $67.3 \%$ các chủng vi khuẩn tìm thấy là vi khuẩn gram âm; $50 \%$ các chủng vi khuẩn tìm thấy là chủng vi khuẩn bệnh viện; Vi khuẩn gây bệnh cao nhất là H.influenzae $22.4 \%$.

Kết quả NC của Nguyễn Thế Tần và Phan Hữu Nguyệt Diễm 40 trẻ mắc VPKD cấy dịch phế quản lần 1 có 30 trường hợp âm tính, 10 trường hợp dương tính chủ yếu là $\mathrm{K}$. Pneumoniae chiếm $40 \%$. Với 22 trường hợp cấy lần 2 vẫn chủ yếu là $K$. Pneumoniae là 7 trường hợp chiếm 43.8\%. Kết quả nuôi cấy lân $3 \mathrm{~K}$. Pneumoniae là 5 trường hợp chiếm $62.5 \%$ [3].

3.2.3. Phân bố virus - nấm gây bệnh

\section{Bảng 3.5. Phân bố virus và nấm gây bệnh}

\begin{tabular}{|c|c|c|}
\hline Virus - Nấm & Số bệnh nhân (51) & Tỷ lệ (\%) \\
\hline Epstein-BarrVirus (EBV) & 3 & 5.9 \\
\hline AdenoVirus & 7 & 13.7 \\
\hline Rhino Virus & 8 & 15.7 \\
\hline Respiratory Syncytical virus (RSV) & 14 & 27.4 \\
\hline Virus Sởi & 5 & 9.8 \\
\hline Cytomegalovirus (CMV) & 5 & 9.8 \\
\hline Cúm A & 3 & 5.9 \\
\hline Nấm & 6 & 11.8 \\
\hline
\end{tabular}

Kết quả $\mathrm{NC}$ phân lập được 51 trường hợp dương tính với virus và nấm, Adeno virus chiếm 13.7\%; Rhino virus chiếm 15.7\%; cao nhất là RSV chiếm 27.4\%; virus Sởi, CMV chiếm 9.8\%; Candida Abicans chiếm 11.8\%. Virus là một trong những yếu tố gây VPKD hay gặp nhất; Virus thường lây truyền qua đường không khí, qua tiếp xúc trực tiếp với nước bọt, dịch tiết bị nhiễm. Chính vì thế, trẻ có thể hay bị tái nhiễm bệnh. 
3.2.4. Phân bố vi sinh vật gây bệnh theo lúa tuổi

Bảng 3.6. Phân bố vi sinh vật gây bệnh theo lứa tuổi

\begin{tabular}{|c|c|c|c|c|c|}
\hline \multirow{2}{*}{ Vi sinh vật } & \multicolumn{2}{|c|}{2 tháng $-<24$ tháng $(\mathrm{n}=92)$} & \multicolumn{2}{|c|}{24 tháng - 72 tháng $(n=18)$} & \multirow{2}{*}{$\mathbf{P}$} \\
\hline & $\mathbf{n}$ & $\%$ & $\mathbf{n}$ & $\%$ & \\
\hline Vi khuẩn $(\mathrm{n}=58)$ & 45 & 77.6 & 13 & 22.4 & 0.019 \\
\hline Virus $(n=46)$ & 41 & 89.1 & 5 & 10.9 & 0.037 \\
\hline Nấm $(\mathrm{n}=6)$ & 6 & 100 & 0 & 0 & 0 \\
\hline
\end{tabular}

Qua kết quả bảng 3.6 cho thấy: Nhóm từ 2 tháng đến $<24$ tháng nhiễm vi khuẩn, virus với tỷ lệ là $77.6 \%$ và $89.1 \%$; Nhiễm Nấm chỉ gặp ở nhóm tuổi từ 2 tháng đến $<24$ tháng. Điều này hoàn toàn hợp lý vì trẻ sau sinh hàng loạt các cơ quan như hô hấp, tim mạch, hệ miễn dịch... mới dân hoàn thiện. Vì thế, trẻ dễ mắc bệnh hơn và tình trạng bệnh cũng nặng hơn [6].

3.2.5. Phân bố từng loại vi khuân gây bệnh theo lưa tuổi

Bảng 3.7. Phân bố từng loại vi khuẩn gây bệnh theo lứa tuổi

\begin{tabular}{|c|c|c|c|c|c|c|c|}
\hline \multirow{2}{*}{ Tuổi } & \multicolumn{2}{|c|}{$\begin{array}{c}\mathbf{2}-\mathbf{2 4} \text { tháng } \\
(\mathbf{n}=\mathbf{4 5})\end{array}$} & $\begin{array}{c}\mathbf{2 4}-\mathbf{7 2} \text { tháng } \\
(\mathbf{n}=\mathbf{1 3})\end{array}$ & \multicolumn{2}{|c|}{$\begin{array}{c}\text { Tổng } \\
(\mathbf{n}=\mathbf{5 8})\end{array}$} & \multirow{2}{*}{$\mathbf{P}$} \\
\cline { 2 - 8 } & $\mathbf{n}$ & $\mathbf{\%}$ & $\mathbf{n}$ & $\mathbf{\%}$ & $\mathbf{n}$ & $\mathbf{\%}$ & \\
\hline Streptococcus pneumoniae & 8 & 13.8 & 3 & 5.2 & 11 & 19 & 0.038 \\
\hline Haemophilus influenzae & 9 & 15.5 & 4 & 6.9 & 13 & 22.4 & 0.048 \\
\hline Acinobacter Baumarini & 3 & 5.2 & 1 & 1.7 & 4 & 6.9 & 0.072 \\
\hline Burkholderia aeruginosa & 8 & 13.8 & 2 & 3.4 & 10 & 17.2 & 0.026 \\
\hline Staphylococcus aureus & 6 & 10.4 & 2 & 3.4 & 8 & 13.8 & 0.072 \\
\hline Klebsiella pneumoniae & 4 & 6.9 & 0 & 0 & 4 & 6.9 & 0 \\
\hline Pseudomonas aeruginosa & 4 & 6.9 & 0 & 0 & 4 & 6.9 & 0 \\
\hline Escherichia Coli & 3 & 5.2 & 1 & 1.7 & 4 & 6.9 & 0.072 \\
\hline
\end{tabular}

Theo bảng 3.7 nhóm vi khuẩn bệnh viện gặp chủ yếu ở trẻ từ 2 tháng đến $<24$ tháng; Những kết quả trên một lần nữa khẳng định rằng nguyên nhân gây VPKD do vi khuẩn ở trẻ < 24 tháng chủ yếu là vi khuẩn Gram âm, từ đó cân có định hướng điều trị sớm các trường hợp VP, kiểm soát tốt chương trình nhiễm khuẩn cấp tính đường hô hấp tránh để trẻ bị VPKD. 


\section{KẾT LUẬN}

Nghiên cứu 120 bệnh nhân mắc VPKD tại khoa Hô hấp Bệnh viện Nhi Thanh Hóa chúng tôi rút ra một số kết luận sau:

Tỷ lệ mắc bệnh VPKD từ 2 tháng đến < 24 tháng là $85 \%$; nam nhiêu hơn nữ với tỷ lệ 1.9:1; đa số các bệnh nhi đã được điều trị trước khi đến viện.

Các tác nhân gây VPKD: Vi khuẩn các loại chiếm $40 \%$, virus các loại chiếm $34.2 \%$, nấm chiếm $5 \%$, đồng nhiễm các loại vi sinh vật chiếm $12.5 \%, 8.3 \%$ không tìm được căn nguyên. Trong 58 vi khuẩn tìm được có 02 chủng vi khuẩn gram dương và có 06 chủng vi khuẩn gram âm; $50 \%$ vi khuẩn tìm thấy thuộc vi khuẩn bệnh viện. Kết quả nghiên cứu phân lập được 51 trường hợp dương tính với virus và nấm, cao nhất là RSV chiếm $27.4 \%$, virus sởi chiếm $9.8 \%$, CMV chiếm tỷ lệ 9.8\%, cúm $\mathrm{A}$ chiếm tỷ lệ $5.9 \%$ và nấm Candida Abicans chiếm $11.8 \%$. Tuổi càng nhỏ thì tỷ lệ nhiễm vi sinh vật càng cao; nhóm từ 2 tháng đến < 24 tháng nhiễm vi khuẩn, virus cao hơn với tỷ lệ là $77.6 \%$ và $89.1 \%$; nhiễm nấm, nhóm vi khuẩn bệnh viện chỉ gặp ở nhóm tuổi từ 2 tháng đến $<24$ tháng.

\section{KIẾN NGH!}

Trong quá trình nghiên cứu chúng tôi có một số đề xuất sau:

5.1. Trẻ $<24$ tháng bị viêm phổi, nhiễm vi khuẩn gram âm dễ mắc VPKD. Đứng trước những trường hợp trên các bác sĩ lâm sàng cần phát hiện sớm và điều trị triệt để, tránh nguy cơ diễn biến thành VPKD.

5.2. Thời gian, phạm vi và nguôn lực của nghiên cứu còn hạn chế do đó đây chỉ mới là những kết quả bước đầu. Để xác định được nguyên nhân gây bệnh VPKD cần có những nghiên cứu với quy mô lớn hơn và chuyên sâu hơn.

\section{TÀI LIỆU THAM KHẢO:}

1. Nguyễn Thị Huyền Nga (2013), Đặc điểm lâm sàng, cận lâm sàng và tính kháng kháng sinh của vi khuẩn gây viêm phổi ở trẻ em tại Bệnh viện Nhi Trung uơng, Luận văn tốt nghiệp bác sỹ chuyên khoa II, Trường Đại học Y Hà Nội.

2. Trần Quy, Trần Thị Hồng Vân (2009), Bệnh viêm phế quản phổi, Bài giảng Nhi khoa tập 1 , nhà xuất bản y học.

3. Nguyễn Thế Tần, Phan Hữu Nguyệt Diễm (2012), "Đặc điểm viêm phổi nằm viện trên 2 tuần tại khoa Hô hấp Bệnh viện Nhi Đồng 1”, Y học TP Hồ Chí Minh, 14(1) tr. $150-154$.

4. Lê Phước Truyền, Phạm Thị Minh Hồng (2010), Đặc điểm Viêm phổi kéo dài tại khoa Hô hấp Bệnh viện Nhi Đồng 2, luận văn tốt nghiệp BS đa khoa, đại học Y Dược Thành phố Hồ Chí Minh.

5. Nguyễn Thị Yến, Nguyễn Thị Quỳnh Hương (2012), Nguyên nhân của viêm phế quản phổi kéo dài ở trẻ em <2 tuổi tại Bệnh vịên Nhi Trung ương, Tạp chí Y học Việt Nam, tập 391, tr 63-66.

6. World Health Organization (2007), “Acute Rerpiratory Infection in children”. 